DOI 10.4467/2543733XSSB.17.008.7254

ANDRZEJ KASTORY

Polska Akademia Umiejętności

\title{
MOCARSTWA ZACHODNIE WOBEC KRYZYSU W POLSCE Z GRUDNIA 1980 R.
}

Słowa kluczowe: Departament Stanu USA, Foreign Office, Rada NATO, polski kryzys 1980, zagrożenie interwencją

Porozumienia podpisane 30 i 31 sierpnia pomiędzy strajkującymi a przedstawicielami władz państwowych sankcjonowały powołanie do życia niezależnego związku zawodowego „Solidarność”. Było to wydarzenie bez precedensu w historii krajów sowieckiego bloku i uruchamiało proces, którego konsekwencji nie można było wówczas przewidzieć. 24 września w warszawskim Sądzie Wojewódzkim złożono wniosek o rejestrację związku. O złej woli władz świadczyła podjęta przez prezesa sądu próba, by ze statutu wykreślić prawo do strajku oraz wprowadzenie zdania o przewodniej roli PZPR. Niemniej wobec groźby strajku powszechnego Sąd Najwyższy przyjął 10 listopada statut Niezależnego Samorządnego Związku Zawodowego Solidarność ${ }^{1}$.

W Centralnej Agencji Wywiadowczej Stanów Zjednoczonych oceniano, że jeśli osiągnięte w sierpniu porozumienia miałyby być dosłownie realizowane, stanowiłyby zagrożenie dla podstaw systemu komunistycznego w Polsce. Istnienie wolnych związków zawodowych i złagodzenie cenzury nie pozwoli partii komunistycznej zachować kontroli nad społeczeństwem. Próby polskich władz, by w procesie demokratyzacji państwa przejąć inicjatywę, mogłyby skłonić Rosjan do działań prewencyjnych. Wówczas powstałaby sytuacja przypominająca ,praska wiosnę” z 1968 r. Rosjanie muszą sobie zdawać sprawę, że antyrosyjskie nastroje panujące w Polsce mogą doprowadzić w razie inwazji do zbrojnego oporu, a próba ponownego podporządkowania sobie Polski wymagałaby operacji największej od czasu II wojny światowej i w konsekwencji skutkowałaby długotrwałą okupacją kraju². Zdaniem Zbigniewa Brzezińskiego, doradcy prezydenta do

1 O tym szeroko Andrzej F r i s z k e, Rewolucja Solidarności 1980-1981, Kraków 2014, s. 125, $128-156$.

2 Foreign Relations of the United States (dalej: FRUS) 1977-1980, vol. VI, Soviet Union (https://history.state.gov/historicaldocuments/frus1977-80v06/d310, dok. 300, Intelligence Memorandum Prepared in the Central Intelligence Agency, 8 września 1980 r., s. 877; o nie najlepszych zamiarach rządzących świadczyła też narada Państwowego Komitetu Obrony w dniu 12 listopada. Gen. Wojciech Jaruzelski sugerował potrze- 
spraw bezpieczeństwa państwowego, nie powinno się w Polsce popierać nadmiernych żądań, bowiem władze, jeśli idzie o ustępstwa, znajdują się u kresu swoich możliwości³.

W Foreign Office oceniano, że sowiecka interwencja w Polsce na krótką metę zaszkodziłaby stosunkom Wschód-Zachód, już i tak poważnie napiętym na skutek sowieckiej inwazji na Afganistan ${ }^{4}$. Rozmiary i trwałość szkód zależałyby od rozmiarów i siły polskiego oporu wobec Rosjan i sił innych państw Układu Warszawskiego. Rosjanie najprawdopodobniej uważaliby, że gdy „,opadnie kurz i porządek zostanie przywrócony”, robocze stosunki z Francją, RFN i Japonią powrócą do poprzedniego poziomu raczej w ciągu kilku miesięcy niż lat. Niewątpliwie osądzają, że Polska po cichu jest uznawana za część ich sfery wpływów, a implikacje doktryny Breżniewa są właściwie rozumiane. W efekcie skutki inwazji na Polskę byłyby zmniejsze niż w wypadku Afganistanu, gdzie agresja dotyczyła nowego obszaru, stwarzając potencjalne zagrożenie dla żywotnych interesów Zachodu. Ponowne podporządkowanie Polski nie naruszyłoby ani strategicznej, ani politycznej równowagi w Europie. Rosjanie traktowaliby konsekwencje interwencji jako nietrwałe, zaś jako trwałe - zagrożenia wynikające z nieinterwencji, ponieważ bezczynność stanowiłaby zachętę dla innych w Układzie Warszawskim 5 .

W analizie przygotowanej 14 października 1980 r. dla Komitetu Politycznego przy Radzie NATO w październiku 1980 r. przyznawano, że Związek Sowiecki ma obiektywne powody do interwencji w Polsce, bowiem pewne punkty porozumień osiągniętych latem tego roku mają w oczach Moskwy charakter kontrrewolucyjny, zwłaszcza powołanie wolnych związków zawodowych i przyznanie pracującym prawa do strajku. Do interwencji mogłoby Rosjan skłonić przekonanie, że polska partia komunistyczna nie zdoła wystarczająco szybko odzyskać utraconej władzy i sytuacja będzie ewoluować w kierunku przypominającym Czechosłowację w 1968 r., zagrażając w ten sposób bezpieczeństwu strategicznemu Związku Sowieckiego i jedności sowieckiego bloku. „Polacy powinni więc przede wszystkim zapobiec, aby fiasko komunizmu nie stało się zbyt oczywiste"6.

Zarówno dla Amerykanów, jak i Brytyjczyków zasadniczym celem było w tym momencie zniechęcanie Rosjan do interwencji, a władz polskich do użycia siły przeciwko związkom zawodowym. Zbigniew Brzeziński uważał, że należy Rosjan przestrzec przed konsekwencjami inwazji na Polskę. Nieuczynienie tego w 1968 r., podczas praskiej wiosny, było - jego zdaniem - błędem i nie chcąc go powtórzyć, posłużył się celowym przeciekiem do mediów, określając sankcje, jakie w przypadku inwazji na Polskę zo-

bę przygotowania niezbędnych przepisów prawnych dotyczących stanu wojennego, Raporty przekazane przez płk. Kuklińskiego, http://wyborcza.pl/1.768426056610 (cyt. dalej: R. Kukliński), John N. McMahon z CIA do Sekretarza Stanu, 16 marca $1981 \mathrm{r}$.

3 Z. B r ze z iń s k i, Cztery lata w Białym Domu. Wspomnienia Doradcy do spraw Bezpieczeństwa Państwa 1977-1981. Przedruk za: Polonia 1986, aneksy, 19 września 1980 r., s. 544.

412 grudnia 1979 r. Biuro Polityczne Komunistycznej Partii Związku Sowieckiego podjęło decyzję o zbrojnej interwencji w Afganistanie, której celem miało być wspieranie prosowiecko nastawionych ugrupowań. Interwencja rozpoczęła się jeszcze w tym miesiącu. 27 grudnia 1979 r. zajęty został Kabul, W. R ojek, Historia nowoczesnych stosunków międzynarodowych, Warszawa 2010, s. 484.

${ }_{5}^{5}$ National Archives, Londyn (dalej: NA), FCO28/4162, dok. „Polityczne koszty sowieckiej interwencji”, bez daty, między dokumentami z września $1980 \mathrm{r}$.

${ }^{6}$ NA, FCO28/4162, stała delegacja Belgii przy NATO, raport dla przewodniczącego Komitetu Politycznego, 14 października $1980 \mathrm{r}$. 
stałyby wdrożone. Wskazywał, że interwencja położyłaby kres odprężeniu, a jej skutkiem byłoby podważenie współpracy gospodarczej między Wschodem i Zachodem, poza tym zwiększenie budżetu NATO, poważne napięcia pomiędzy zachodnioeuropejskimi partiami komunistycznymi a Związkiem Sowieckim, w dodatku zraziłaby do Moskwy państwa niezaangażowane i, być może, doprowadziłaby do zamieszek w innych krajach sowieckiego bloku, wreszcie do jawnej współpracy wojskowej Stanów Zjednoczonych z Chinami ${ }^{7}$.

Rejestracja „Solidarności” nie przyniosła na długo poprawy atmosfery. 20 listopada milicja dokonała rewizji w siedzibie mazowieckich władz Solidarności. W wyniku przeszukania aresztowała Jana Narożniaka z wydawnictwa „Solidarności” oraz Piotra Sapełę, pracownika powielarni w Prokuraturze Generalnej, który Narożniakowi dostarczył instrukcje Prokuratora Generalnego dotyczące traktowania ,antysocjalistycznej” opozycji. Wobec groźby strajku powszechnego w Regionie Mazowsze obu aresztowanych zwolniono, jednak zaufanie do władz zostało podważone ${ }^{8}$. W Foreign Office odnotowywano wzrost napięcia w Polsce. Pojawiły się opinie, że władze warszawskie, aby zapewnić sobie kontrolę nad sytuacją, mogą posłużyć się siłą, a jeśli im się nie uda, zwrócą się do Rosjan o pomoc ${ }^{9}$. Niewątpliwie na sposobie myślenia brytyjskich dyplomatów ciążyła znajomość technik zastosowanych wcześniej przez Rosjan w odniesieniu do Węgier w 1956 r. i Czechosłowacji w 1968 r. Janusz Onyszkiewicz, jeden z założycieli mazowieckiej „Solidarności”, członek prezydium Regionu Mazowsze, przyznał w rozmowie z brytyjskim dyplomatą, że gdy partia straci kontrolę, wówczas czołgi zostaną wysłane. Żartując, miał oświadczyć, że ,, Solidarność” chciałaby partii pomoc, ale nie wie jak ${ }^{10}$.

W raporcie brytyjskiej ambasady w Moskwie z 27 listopada stwierdzano, że wzrosło ryzyko sowieckiej interwencji w Polsce. Jeśli partia nie będzie w stanie o własnych siłach zapewnić sobie kontroli nad państwem, sowiecka interwencja stanie się nieuchronna. Dla Rosjan byłoby najlepiej, gdyby podjęli działania na prośbę polskiego rządu, unikając bezpośredniego starcia z armią polską. Oceniano, że inwazja zapewne nie nastąpi w najbliższym czasie, ale zawsze pozostanie wyborem desperackim, choć z militarnego punktu widzenia mogłaby odnieść szybki i decydujący sukces. Rosjanie być może wytrzymają do wiosny 1981 r., ufając, że polska partia odzyska w ten czy inny sposób kontrolę, jednak ich cierpliwość jest bardzo wątła ${ }^{11}$. Margaret Thatcher na konferencji prasowej w dniu 28 listopada oceniała, że Rosjanie nadal są skłonni dać czas Stanisławowi Kani na odzyskanie kontroli nad sytuacją ${ }^{12}$. Niemniej brytyjski rząd postanowił nie odnawiać umowy kredytowej ze Związkiem Sowieckim, wygasającej w lutym 1981 r. Z zadowoleniem

7 Z. Brzeziński, Cztery lata w Białym Domu..., s. 443, 445; też aneksy, zapis z 26 listopada 1980 r., S. 547.

${ }^{8}$ A. Friszke, Rewolucja Solidarności 1980-1981, s. 161-176; J. Holzer, , Solidarność” 1980-1981. Geneza i historia, Warszawa 1983, s. 101-103; Stanisław Kania, Zatrzymać konfrontację, Wydawnictwo „BGW”, brak daty wydania, s. 78-79.

${ }^{9}$ NA, FCO28/4164, dok. z 26 listopada 1980 r.; też Telegram z Warszawy do brytyjskiej delegacji przy NATO, 26 listopada 1980 r.; brytyjska delegacja przy radzie NATO do Foreign Office, 25 listopada 1980 r.

10 NA, FCO28/4164, Miss S.E. Ross z Warszawy do Roberta Faceya z Foreign Office 27 listopada $1980 \mathrm{r}$.

11 NA, FCO28/4164, ambasada w Moskwie do Foreign Office, „Sowiecka polityka wobec Polski”, podpisany Curtis Kneble, 27 listopada 1980 r.

12 NA, FCO28/4164, briefing premiera, 28 listopada $1980 \mathrm{r}$. 
przyjęto też decyzję Wspólnoty Europejskiej ze stycznia 1980 r., by nie zastępować zawieszonego przez Stany Zjednoczone eksportu rolniczego do Związku Sowieckiego ${ }^{13}$.

W siedzibie NATO w Brukseli trwały dyskusje na temat groźby sowieckiej interwencji w Polsce. Dnia 2 grudnia w godzinach przedpołudniowych zebrała się w ścisłym gronie Rada Paktu. Amerykanie oceniali, że sowieckie przygotowania wojskowe do interwencji w Polsce są bardzo zaawansowane. Wprawdzie zaobserwowano ożywiony ruch połączonych sił lotnictwa sowieckiego, czechosłowackiego i wschodnioniemieckiego, ale na razie nie podjęto decyzji o inwazji. Rosjanie zdają sobie sprawę, że mogłaby ona mieć krwawy charakter i przynieść trudne do przewidzenia konsekwencje dla stosunków Wschód-Zachód ${ }^{14}$.

Wieczorem 2 grudnia Sekretarz Generalny NATO zwołał posiedzenie przewodniczących delegacji, którym przedstawił analizę sytuacji, dostarczoną przez dowództwo Paktu. Wedle najnowszych danych wywiadowczych Rosjanie postawili w stan gotowości 33 dywizje przeznaczone do napaści na Polskę. Pod broń powołano rezerwistów, a dowództwo wojskowe ulokowano w zachodnich rejonach Związku Sowieckiego. Rosjanie w swoich planach zakładają, że polska armia będzie w stanie stawiać im opór przez 14 dni. W przypadku inwazji dowództwo NATO proponowało aktywizację kwatery głównej, przegląd planów, testowanie łączności i przygotowanie rakiet SAM do szybkiego użycia. Oceniano, że mało prawdopodobne jest rozpoczęcie operacji przed 15 grudnia, zanim grunt dla działań czołgów będzie wystarczająco twardy. Poza tym wiadomo było, że dopiero 15 grudnia Breżniew ma powrócić z wizyty w Indiach ${ }^{15}$. W dyskusji stwierdzono, że Rosjanie są przygotowani militarnie i w dużej mierze politycznie do uderzenia na Polskę w najbliższych dniach, a nawet godzinach. Nie chcą tego, ale się nie zawahają, jeśli uznają, że powstała taka konieczność. W podsumowaniu dyskusji stwierdzano, że w Moskwie nie zdecydowano się jeszcze wkroczyć, ale poczynione przygotowania pozwolą to uczynić w wybranym momencie ${ }^{16}$. W Foreign Office oceniano, że w rosyjskiej tradycji i charakterze leży użycie wystarczających sił, by nie dopuścić do przegranej. Wysłanie garstki dywizji byłoby ryzykowane, choć zakładano, że działania polskich sił bezpieczeństwa pozwolą Rosjanom pozostać w rezerwie. Miano jednak wątpliwości, czy ktokolwiek wysoko uplasowany w polskim kierownictwie wezwałby Rosjan. Raczej doszłoby do wymiany kierownictwa i wystosowania zaproszenia przez jakiegoś quislinga ${ }^{17}$.

Prezydent Jimmy Carter w oświadczeniu z 3 grudnia mówił, że Stany Zjednoczone z rosnącym niepokojem obserwują bezprecedensowy wzrost liczby sowieckich wojsk wzdłuż granicy z Polską. Odnotowano też sowieckie wypowiedzi na temat antysocjalistycznych sił w Polsce.

Wiemy z powojennej historii, że takie wypowiedzi często poprzedzały interwencję. Stany Zjednoczone nadal wierzą, że naród i rząd polski będą mogli rozwiązać swoje problem bez zewnętrznej ingerencji i nie zamierzają wykorzystywać polskich trudności dla swoich celów.

\footnotetext{
13 NA, FCO28/4164, Foreign and Defence Debate, notatka zarejestrowana 1 grudnia 1980 r.

14 NA, FCO28/4164, raport brytyjskiej delegacji przy NATO, 2 grudnia $1980 \mathrm{r}$.

15 NA, FCO28/4164, raport brytyjskiej delegacji przy NATO, 2 grudnia $1980 \mathrm{r}$.

${ }^{16}$ NA, FCO28/4164, brytyjska delegacja przy NATO do Foreign Office, 2 grudnia 1980 r.

17 NA, FCO28/4164, 2 grudnia 1980 r.
} 
W depeszy skierowanej tego dnia do Leonida Breżniewa prezydent podkreślał, że Stany Zjednoczone są absolutnie zdecydowane nie wyzyskiwać wypadków w Polsce, ani nie zamierzają zagrażać usprawiedliwionym interesom bezpieczeństwa Związku Sowieckiego w tym rejonie. Stanom Zjednoczonym zależy jedynie na zachowaniu pokoju w Europie Środkowej, który pozwoli rządowi polskiemu i narodowi polskiemu rozwiązać swoje wewnętrzne trudności. Narzucenie narodowi polskiemu siłą jakiegoś rozwiązania, pisał Carter, wpłynęłoby jak najbardziej negatywnie na stosunki amerykańsko-sowieckie ${ }^{18}$. Sekretarz Stanu Edmund Musky zapytany przez dziennikarza „Washington Post”, czy Stany Zjednoczone użyłyby własnych sił w wypadku sowieckiej interwencji w Polsce, odparł: „,powinniśmy Rosjan pozostawić w stanie niepewności”, ${ }^{\text {, }}$.

Deklaracja Rady Europejskiej EWG z 2 grudnia nie pozostawiała żadnej wątpliwości, że w wypadku sowieckiej interwencji Wspólnota przewiduje jedynie działania dyplomatyczne. Stwierdzano mianowicie, że stanowisko „Dziewiątki”"20 będzie zgodne z Kartą Narodów Zjednoczonych i Aktem Końcowym z Helsinek. Wzywając wszystkie kraje, by w odniesieniu do Polski i narodu polskiego stosowały się do tych zasad, deklarowano na koniec udzielenie Polsce, w granicach możliwości, pomocy ekonomicznej ${ }^{21}$.

Zniechęcanie Rosjan do interwencji znalazło wyraz w rozmowach prowadzonych w różnych stolicach. Indagowany w Lizbonie sowiecki dyplomata oświadczył, że Zachód nie powinien niepokoić się o Polskę, bowiem znajduje się ona w sowieckiej strefie wpływów $^{22}$. We włoskim ministerstwie spraw zagranicznych Rosjanie wskazywali, że przeniesienie niepokojów z Polski do innych krajów bloku ,,grozi destabilizacją Układu Warszawskiego”. Gdyby szybkie rozładowanie kryzysu siłami polskimi okazało się niemożliwe, ,państwa Układu Warszawskiego będa musiały podjąć zdecydowaną kontrakcję, do bezpośredniej interwencji militarnej wtacznie",23.

Pierre Trudeau, premier Kanady, w liście z 5 grudnia do Breżniewa zwracał uwagę, że polski kryzys ma polskie źródła, zatem powinien zostać rozwiązany przez samych Polaków. Podkreślał, że Kanada rozumie interesy bezpieczeństwa Związku Sowieckiego, zwłaszcza jeśli odnoszą się do Europy Środkowej, ale argumenty, że kraje zachodnie zorganizowały polski kryzys, aby wyciągnąć z niego korzyści, zagrażając bezpieczeństwu Układu Warszawskiego lub samego Związku Sowieckiego, są bezpodstawne. Nie ma więc żadnych podstaw do ingerencji w wewnętrzne sprawy Polski. Interwencja zbrojna zagrozi odprężeniu ${ }^{24}$. Austriacki minister spraw zagranicznych Willibald Pahr uważał, że sowiecka interwencja w Polsce jest nieuchronna. Dnia 4 grudnia w rozmowie ze swoim brytyjskim kolegą Peterem Carringtonem zakładał, że rząd polski będzie zwlekał do Bożego Narodzenia, gdy ludzie będą w domach, a fabryki będą puste. Na początek Kania mógłby użyć własnych sił, następnie, skoro tylko armia zostałaby przy pomocy Rosjan sparaliżowana, siły bezpieczeństwa podjęłyby działania przeciwko społeczeństwu. Pahr

18 A. B rzezińs ki, Cztery lata w Białym Domu..., aneksy, zapis z 3 grudnia 1980 r., s. 548.

19 NA, FCO28/4164, raport z Waszyngtonu, 4 grudnia $1980 \mathrm{r}$.

${ }^{20}$ W grudniu 1980 r. Wspólnotę Gospodarczą tworzyły: Francja, RFN, Włochy, Belgia, Holandia, Luksemburg, Wielka Brytania, Irlandia i Dania.

${ }^{21}$ NA, FCO28/4165, raport z Luksemburga w języku francuskim z 18 grudnia 1980 r.

${ }^{22}$ NA, FCO28/ 4164, raport brytyjskiej delegacji przy NATO, 4 grudnia $1980 \mathrm{r}$.

23 A. Fris z k e, Rewolucja Solidarności 1980-1981..., s. 181.

${ }^{24} \mathrm{NA}, \mathrm{FCO} 28 / 4165,5$ grudnia $1980 \mathrm{r}$. 
wykluczał reakcję wojskową Stanów Zjednoczonych, a zdaniem Carringtona Amerykanie w razie sowieckiej inwazji będą nalegać, aby kraje europejskie zastosowały restrykcje ekonomiczne przeciwko Związkowi Sowieckiemu. Przyznał jednak, że będzie to trudne, zwłaszcza dla RFN, zależnej od rosyjskich dostaw energetycznych. Pahr z zadowoleniem przyjął oświadczenie Sekretarza Generalnego NATO Josepha Lunsa, że pakt nie będzie reagować militarnie na sowiecką interwencję w Polsce. W konsekwencji Solidarność nie może robić sobie jakichkolwiek iluzji ${ }^{25}$. Wątpliwości co do postawy rządu RFN miał Zbigniew Brzeziński, oceniający ją jako powściągliwą. Jednak ambasador niemiecki przekonywał go w rozmowie z 4 grudnia, że opinia publiczna zmusi rząd do zastosowania sankcji ekonomicznych, gdyby doszło do sowieckiej inwazji na Polskę ${ }^{26}$.

Marian Dobrosielski, przewodniczący polskiej delegacji na madryckiej sesji Konferencji Bezpieczeństwa i Współpracy w Europie (rozpoczęła się 11 listopada), w rozmowie z brytyjskim dyplomatą stwierdził, że nowe związki zawodowe dokonały już czegoś w Polsce. Z władz odeszli , twardogłowi”, ale dalsze posuwanie się w kierunku rozmontowywania ,socjalistycznego” państwa może przynieść fatalne konsekwencje. W rozmowie z hiszpańskim wiceministrem spraw zagranicznych Dobrosielski powiedział, że jeśli Rosjanie zaatakują, to Polacy będą walczyć do ostatniego człowieka i będzie to o wiele gorsze niż na Węgrzech w 1956 r. Oceniał, że madryckie spotkanie zapewnia pewną ochronę dla Polski, ale nie pomoże, jeśli podstawy socjalizmu zostaną zagrożone. Zdaniem brytyjskiego rozmówcy Dobrosielski wypowiadał się, jakby tracił nerwy. Nie jest wykluczone, pisał, że on i niektórzy inni wschodnioeuropejscy politycy mogliby w Madrycie prosić o azyl ${ }^{27}$. Sekretarz Stanu Edmund Musky sceptycznie oceniał madryckie prace KBWE. Jego zdaniem Związek Sowiecki był zainteresowany porozumieniami helsińskimi tylko w celu legitymizacji granic stworzonych po II wojnie światowej, aby zamknąć za nimi mieszkające tam społeczeństwa. Na posiedzeniu Rady Atlantyckiej w dniu 12 grudnia mówił, że stosunki Wschód-Zachód w dotychczasowym kształcie nie przetrwają, jeśli sowieckie działania, takie jak w Afganistanie, pozbawią jakiś kraj prawa do niepodległości i integralności terytorialnej. Nie może być żadnych wątpliwości w odniesieniu do Polski i jej prawa do decydowania o biegu wydarzeń u siebie. Jeśli dojdzie do zewnętrznej interwencji, to cała sytuacja międzynarodowa ulegnie zmianie. Potężna sowiecka machina wojenna jest czynna w Afganistanie i stale rośnie na europejskich granicach państw należących do Sojuszu ${ }^{28}$. Jednak podejmowane przez NATO środki militarne miały wyłącznie charakter obronny. 9 grudnia zadecydowano, że flota atlantycka (Stanaforland) po jesiennych manewrach nie zostanie rozproszona. Okręty miały pozostać w portach macierzystych, a należące do Stanów Zjednoczonych i Kanady skierowano do Portsmouth. Załogi odwołano z urlopów. Zastrzeżono, że wejście okrętów na Bałtyk będzie możliwe jedynie za jednomyślną zgodą wszystkich państw dostarczających flotę. Ponadto Najwyższe Sojusznicze Dowództwo w Europie postanowiło rozmieścić 4 amerykańskie samoloty AWACS na terenie Niemiec, co miało zwiększyć zdolność NATO do monitorowania rozwoju wydarzeń na terenie Polski. Oceniano, że podjęte środki nie dają

25 NA, FCO28/4165, notatka z rozmowy P. Carringtona z W. Pahrem, 4 grudnia 1980 r.

${ }^{26}$ Z. B rze zińs ki, Cztery lata w Białym Domu..., aneks, zapis z dziennika z 4 i 5 grudnia 1980 r., s. 550.

27 NA, FCO28/4164, raport z Madrytu z 5 grudnia 1980 r.

28 Archiwum NATO, Bruksela, C-VR (80), Spotkanie Rady Atlantyckiej na sesji ministerialnej, 12 grudnia 1980 r. 
powodów do oskarżeń, jakoby NATO ingerowało w wewnętrzne sprawy Polski ${ }^{29}$. Na konferencji prasowej, zorganizowanej po pierwszym dniu obrad Rady NATO, jej rzecznik prasowy na pytanie, co Pakt uczyni w wypadku sowieckiej interwencji, odparł: ,nie chciałbym dyskutować nad taka niepożądana hipoteza. Sednem dzisiejszej dyskusji byto przekonanie, że sowiecka interwencja nie jest nieunikniona"’30.

Sojusznicy nie zamierzali interweniować, ani dostarczać Rosjanom pretekstu do interwencji. Niemniej gdyby do niej doszło, brano pod uwagę protestacyjne démarches, pilne zwołanie Rady Bezpieczeństwa ONZ i Zgromadzenia Ogólnego, prowadzenie kampanii potępiającej interwencję, wezwanie na konsultacje ambasadorów z Moskwy, zawieszenie udziału w madryckich pracach KBWE, zawieszenie wizyt, wreszcie restrykcje handlowe ${ }^{31}$.

W brytyjskiej ambasadzie w Warszawie miano wątpliwości, czy Polska zdoła sama uporządkować sytuację wewnętrzną. Rosjanie, przyznawano, mają rację, że w Polsce istnieją elementy antysocjalistyczne. Oceniając z grubsza, jest ich około $32 \mathrm{mln}$ i gdyby Polska była wyspą na Pacyfiku, z pewnością nie miałaby reżimu komunistycznego. Nie jest jednak wyspą. Wielu Polaków w jakiejś mierze zgadza się na jakiegoś rodzaju socjalizm i lenną zwierzchność Moskwy, choć podporządkowanie Moskwie jest czymś, czego najbardziej nie znoszą. Stanowczo jednak nie akceptują bezsensownego i nieodpowiedzialnego biegu rzeczy, z jakim mają do czynienia dotychczas. Nieskuteczność reżimu była mniej dostrzegana w okresie wzrostu gospodarczego. Teraz to pękło jak bańka mydlana. Ludzie czują, że rząd ich okłamywał bardziej, niż sądzono, i kierował gospodarką w sposób niekompetentny ${ }^{32}$.

Reakcje sowieckiego kierownictwa na wydarzenia w Polsce od samego początku były negatywne. 25 sierpniu 1980 r. powołano do życia ściśle tajną komisję do spraw polskich przy Komitecie Centralnym Komunistycznej Partii Związku Sowieckiego, na której czele stanął członek Biura Politycznego Michaił Susłow. Komisja nie tylko systematycznie dostarczała kierownictwu informacji na temat sytuacji w Polsce, ale formułowała stosowne zalecenia. Porozumienia sierpniowe oceniano na posiedzeniu Biura Politycznego w dniu 3 września jako , legalizację opozycji antysocjalistycznej ”33. Zastąpienie Edwarda Gierka przez Stanisława Kanię w dniu 5 września przyjęto z zadowoleniem, licząc na bardziej energiczne działania nowego kierownictwa. W związku z planowaną w Moskwie wizytą Stanisława Kani i premiera Józefa Pińkowskiego dyskutowano nad stanem rzeczy w Polsce na posiedzeniu sowieckiego Biura Politycznego w dniu 29 października. Leonid Breżniew, mówiąc o „rozpasaniu kontrrewolucji”, brał pod uwagę możliwość wprowadzenia w Polsce stanu wojennego. Polskim przywódcom zamierzano polecić rozpoczęcie ofensy-

${ }^{29}$ NA, FCO28/4165, raport delegacji brytyjskiej przy NATO, 9 grudnia 1980; ibidem, dokument: Line to take for Prime Minister, 11 grudnia $1980 \mathrm{r}$.

30 NA, FCO28/4165, konferencja prasowa z 12 grudnia $1980 \mathrm{r}$.

31 Archiwum NATO, Bruksela, sygn. PO(80)133, dok. Cele Zachodu w polskim kryzysie, 23 grudnia $1980 \mathrm{r}$.

32 NA, FCO28/4165, raport z Warszawy, 12 grudnia $1980 \mathrm{r}$.

33 Iniessa S. Jażborowskaja, Moskwa a ,kryzys polski” lat 1980-1981, [w:] Białe plamy. Czarne plamy. Sprawy trudne w polsko-rosyjskich stosunkach 1918-2008, red. Adam Rotfeld, Anatolij Torkunow, Warszawa 2010, s. 552; zdaniem Andrzeja Paczkowskiego przedstawione wówczas instrukcje komisji M. Susłowa były ogólnikowe i zalecały elastyczność oraz stosowanie „wyważonych środków administracyjnych”. A. P a c zk ow s ki, Moskwa a ,kryzys polski” z lat 1980-1981, [w:] Białe plamy. Czarne plamy. Sprawy trudne w polsko-rosyjskich stosunkach 1918-2008..., s. 541. 
wy przeciwko kontrrewolucji, nie tylko pokojowymi metodami ${ }^{34}$. Nazajutrz w rozmowie z Kanią Breżniew zachęcał do podjęcia przez partię kontrofensywy i zalecał, żeby mieć na uwadze kondycję armii, sił porządku publicznego oraz kontrolę nad środkami informacji. Zapewnił też udzielenie Polsce 465 mln dolarów w formie bezzwrotnej pomocy na wsparcie gospodarki $\mathrm{i}^{35}$.

Wedle relacji Wojciecha Jaruzelskiego 1 grudnia do Moskwy udał się na zaproszenie szefa sowieckiego sztabu, marszałka Nikołaja Ogarkowa gen. Tadeusz Hupałowski, pierwszy zastępca szefa polskiego sztabu. Podczas spotkania z udziałem przedstawicieli sztabów Czechosłowacji i NRD poinformowano Hupałowskiego o planowanych ćwiczeniach wojsk Układu Warszawskiego na terenie Polski. Do Polski ich pierwszy rzut w sile 18 dywizji, w tym 15 sowieckich, 2 czechosłowackich i jednej z NRD, miałby wkroczyć 8 grudnia. W dniu 3 grudnia Naczelny Dowódca Zjednoczonych Sił Zbrojnych Układu Warszawskiego, marszałek Wiktor Kulikow poprosił o zgodę na przyjęcie gotowości do rozpoczęcia ćwiczeń „Sojuz 80 ” na 8 grudnia $1980 \mathrm{r} \cdot{ }^{36}$ Nieco inaczej pisał o tym 3 grudnia w liście do CIA Ryszard Kukliński. Donosił mianowicie, że na polecenie ministra obrony Wojciecha Jaruzelskiego gen. Tadeusz Hupałowski i gen. Franciszek Puchała $^{37}$ zatwierdzili w siedzibie sowieckiego Sztabu Generalnego plan wprowadzenia oddziałów sowieckich, czechosłowackich i wschodnioniemieckich na terytorium Polski pod pretekstem manewrów. W sumie w pierwszej fazie operacji wziąć miało udział, jak wyżej wspomniano, 18 dywizji. Do armii czeskiej i wschodnioniemieckiej miano by dołączyć 4 polskie dywizje. Termin gotowości do przekroczenia polskiej granicy wyznaczono na 8 grudnia. Generał Florian Siwicki, pisał Kukliński, miał przekonywać Jaruzelskiego, by sprzeciwił się tym zamierzeniom, ale "ten przeraźliwie roztrzęsiony stugus Moskwy nawet nie dopuścit do dyskusji na ten temat". Niemniej, odnotował Kukliński, pod naciskiem generałów Floriana Siwickiego i Eugeniusza Molczykaa Jaruzelski zatwierdził przygotowanie do 7 grudnia planu alternatywnego, przewidującego użycie wyłącznie sił polskich ${ }^{39}$.

Szef Centralnej Agencji Wywiadowczej Stanów Zjednoczonych Stansfield Turner, najwyraźniej korzystając z doniesień Kuklińskiego, informował 4 grudnia 1980 r. prezydenta Jimmy'ego Cartera, że Moskwa przygotowała plan interwencji w Polsce, z którym zapoznano polskie dowództwo wojskowe. Interwencja miałaby nastąpić pod pretekstem

${ }^{34}$ I. J a ż borowskaja, Moskwa a kryzys polski.., s. 553, relacja z posiedzenia sowieckiego Biura Politycznego w dniu 29 października 1980 r.; A. F ri s z k e, Rewolucja Solidarności 1980-1981..., s. 180, 183-184; pracownicy KC KPZR na polecenie Michaiła Susłowa wyszukali w Konstytucji PRL zapis o możliwości wprowadzenia stanu wojennego, ibidem, s. 185.

35 S. Kania, Zatrzymać kontrrewolucję, s. 70-73; I. Jażborowskaja, Moskwa a kryzys polski..., S. 555.

${ }^{36}$ Wojciech J aru ze 1 s k i, Stan wojenny. Dlaczego... Współpraca Marek Jaworski, Włodzimierz Łoziński, Warszawa 1992, s. 36; I. Jażborowskaj a, Moskwa a kryzys polski..., s. 557; A. P a c zkow ski, Moskwa a kryzys polski lat 1980-1981..., s. 543.

${ }^{37}$ Gen. Tadeusz Hupałowski był w tym czasie I zastępcą szefa Sztabu Generalnego gen. Floriana Siwickiego, a gen. Franciszek Puchała członkiem sztabu.

${ }^{38}$ Gen. Eugeniusz Molczyk w tym czasie był wiceministrem obrony i zastępcą naczelnego dowódcy Zjednoczonych Sił Zbrojnych Państw Stron Układu Warszawskiego.

39 A. F r i z z e, Rewolucja Solidarności 1980-1981..., s. 188-189; Benjamin We is e r, Ryszard Kukliński. Życie ściśle tajne, Warszawa 2005, s. 197-198. 
ćwiczeń połączonych sił sowieckich, wschodnioniemieckich i czechosłowackich. Gotowość do przekroczenia polskiej granicy wyznaczono na 8 grudnia. Plan przewiduje użycie 15 sowieckich dywizji i jednej armii w składzie dwóch czechosłowackich i jednej wschodnioniemieckiej dywizji. W pierwszej fazie siły interwencyjne miałyby liczyć 18 dywizji. Cztery dodatkowe dywizje miałyby zostać dołączone do sił czechosłowackich i niemieckich. Polityczna decyzja o interwencji podjęta została jakiś czas temu i choć ani Kania, ani minister obrony Wojciech Jaruzelski nie wyrazili sprzeciwu, w polskich kołach wojskowych ujawniła się na wysokim szczeblu opozycja. Opracowano więc alternatywny plan polski, który zakłada, że dla przywrócenia wewnętrznego bezpieczeństwa w kraju użyje się wyłącznie polskich sił podległych Ministerstwu Spraw Wewnętrznych. Plan ten ma być przedłożony Rosjanom 7 grudnia, wraz z aneksem mówiącym o wprowadzeniu sił Układu Warszawskiego, gdyby polskie zawiodły. Należy oczekiwać, że na rozpoczynającym się w Moskwie 4 grudnia spotkaniu szczytu Układu Warszawskiego, z udziałem I sekretarzy i ministrów spraw zagranicznych, ostateczne decyzje zostaną podjęte. Jedynym punktem w porządku obrad ma być sprawa Polski ${ }^{40}$.

Informacje zawarte $\mathrm{w}$ analizach Turnera na polecenie prezydenta przekazano rządom sojuszniczym i niektórym państwom neutralnym i, jak odnotował Brzeziński, zostały dobrze wykorzystane do pozbawienia Związku Sowieckiego przewagi wynikającej z zaskoczenia ${ }^{41}$. Z zaniepokojeniem przyjęto jednak w Białym Domu wypowiedź ambasadora Anatolija Dobrynina, który w rozmowie z przewodniczącym amerykańsko-sowieckiej Rady Handlowej oświadczył, że Związek Sowiecki nie może tolerować w Polsce dwóch oddzielnych rządów. Dostrzegano w tych słowach zapowiedź ewentualnej sowieckiej inwazji ${ }^{42}$. Następne dni były pełne napięcia. W sobotę 6 grudnia Turner na naradzie w Białym Domu potwierdzał, że Rosjanie mogą wkroczyć do Polski w ciągu najbliższych 48 godzin. Podczas kolejnej narady w niedzielę 7 grudnia zaakceptowano tekst oświadczenia dla mediów, w którym stwierdzano, że sowieckie przygotowania do inwazji na Polskę zostały ukończone. Podobną informację przekazano rządom sojuszniczym i przywódcom Kongresu Stanów Zjednoczonych. Brzeziński osobiście zatelefonował do Jana Pawła II z tą informacją. Jana Nowaka Jeziorańskiego, szefa Radia Wolna Europa, Brzeziński poprosił, aby swoimi kanałami uprzedził przywódców polskiej opozycji o konieczności ukrycia się. Ponieważ następnego dnia, 8 grudnia rozpoczynała się wizyta Leonida Breżniewa w Indiach, depeszę o możliwości sowieckiej interwencji w Polsce przesłano również pani premier Indii, Indirze Gandhi ${ }^{43}$.

${ }^{40}$ FRUS 1977-1980, vol. VI, Soviet Union, dok. 312 Dyrektor CIA S. Turner do Prezydenta J. Cartera, Wiceprezydenta Mondale'a, Sekretarza Stanu E. Muskiego, Sekretarza Obrony Browna, I Asystenta Prezydenta do spraw Narodowego Bezpieczeństwa Z. Brzezińskiego, 5 grudnia 1980 r (data informacji 4 grudnia 1980 r.), s. 917; krytyczna opinia o raportach S. Turnera: Z. B rze zi ń s k i, Cztery lata w Biatym Domu... s. 29, s. 444; R. Kukliński przekazywał informację, której nie mógł zweryfikować, że W. Jaruzelski zaoponował przeciwko planom Moskwy. Miało go zwłaszcza zdenerwować żądanie, aby Polskie Wojsko pozostało w koszarach podczas sowieckiej interwencji, a także to, że w interwencji miałyby wziąć udział jednostki wschodnioniemieckie, B. We is e r, Ryszard Kukliński..., s. 195.

${ }^{41}$ Z. B r zeziń s ki, Cztery lata w Białym Domu..., s. 445, też aneks, zapis w dzienniku z 5 grudnia 1980 r., S. 550 .

${ }^{42}$ Z. Brzezińs ki, Cztery lata w Białym Domu..., aneks, zapis w dzienniku z 5 grudnia 1980 r.

${ }^{43}$ Z. Brzeziński, Cztery lata w Białym Domu..., aneks, zapis w dzienniku z 6 i 7 grudnia 1980 r., s. $551-555$. 
4 grudnia 1980 r. do Moskwy udała się polska delegacja z udziałem I sekretarza Stanisława Kani, premiera Józefa Pińkowskiego, sekretarzy Komitetu Centralnego PZPR Kazimierza Barcikowskiego i Stefana Olszowskiego oraz ministra spraw zagranicznych Józefa Czyrka, obrony Wojciecha Jaruzelskiego i ministra spraw wewnętrznych Mirosława Milewskiego. Nazajutrz w Moskwie rozpoczęło się spotkanie przywódców państw Układu Warszawskiego. Delegację polską poddano ostrej krytyce. Reprezentujący Czechosłowację Gustáv Husák i Węgry János Kádár radzili podjąć energiczne działania, a Erich Honecker z NRD zalecał zmianę polskiego kierownictwa i wprowadzenie do Polski wojsk sojuszniczych ${ }^{44}$. Od Kani uzyskano obietnicę, że nie będzie dalszego cofania się przed ,elementami antysocjalistycznymi”, a partia, milicja i wojsko zapanują nad sytuacją ${ }^{45}$. W rozmowie z Breżniewem, przeprowadzonej w cztery oczy, Stanisław Kania przestrzegał przed skutkami interwencji. ,, Nawet gdyby przyszli do Polski sami aniołowie, to i tak musza zostać krwawymi okupantami, i to na całe lata”. Jego zdaniem nie dałoby się uniknąć rozlewu krwi. Jak odnotował Kania, Breżniew miał na koniec oświadczyć: „Dobrze, nie wejdziemy. A jak sytuacja sie pogorszy, to wejdziemy, wejdziemy, ale bez ciebie nie wejdziemy" ${ }^{46}$. Iście pytyjskie stanowisko, ale jakkolwiek te słowa interpretować, było jasne, że do interwencji w bezpośredniej przyszłości raczej nie dojdzie. Jeszcze tego dnia wieczorem z Moskwy wysłano rozkazy odwołujące przewidzianą na 8 grudnia operację wojskową przeciwko Polsce ${ }^{47}$.

Marshall Brement z Narodowej Rady Bezpieczeństwa w memoriale dla prezydenta z 9 grudnia informował, że większość analiz CIA przewiduje wkroczenie Rosjan do Polski być może jeszcze podczas obecnego weekendu (to znaczy 13/14 grudnia). Opinię tę oparto na założeniu, że sowieckie siły są już przygotowane do inwazji i cofnięcie decyzji na tym etapie nie jest możliwe. Datę rozpoczęcia inwazji wybrano tak, aby nie dopuścić do demonstracji związanych z rocznicą strajków z grudnia 1970 r. Brement podawał w wątpliwość zasadność tej prognozy. Dokonując inwazji na Polskę, pisał, Rosjanie muszą się liczyć z międzynarodową reakcją pogłębiającą trudności gospodarcze Związku Sowieckiego; z oporem zbrojnym ze strony Polski; osłabieniem sił Układu Warszawskiego i innymi trudnymi do przewidzenia konsekwencjami. Brement uważał, że Rosjanie nie wejdą, jeśli nie będą całkowicie przekonani, że polskie kierownictwo utraciło wszelkie szanse na znalezienie modus vivendi możliwego do przyjęcia dla Breżniewa. Mogą się ruszyć

44 I. J a ż b orows ka ja, Moskwa a kryzys polski.., s. 556.

${ }^{45}$ O przebiegu narady: Stanisław Kania, Zatrzymać konfrontację..., s. 86-90; nieco obszerniej W. Jaruzels ki, Stan wojenny..., s. 37-43.

${ }^{46}$ St. Kania, Zatrzymać konfrontację..., s. 91-92; A. Friszke, Rewolucja Solidarności 1980-1981..., s. 192-193; I. Jażborowskaja, Moskwa a kryzys polski..., s. 556 przytacza nieco inną interpretację tej wypowiedzi. Breżniew miał powiedzieć: „Jeśli zobaczymy, że was obalają, to wejdziemy”; treść tej rozmowy Stanisław Kania przekazał 16 grudnia 1980 r. Mieczysławowi Rakowskiemu, M.F. Rak ow s k i, Dzienniki polityczne 1979-1981, Warszawa 2004, zapis z 16 i 18 grudnia, s. 305, 306. Kania utrzymywał w tej rozmowie, że Breżniew odwołał uruchomienie ćwiczeń Sojuz 80 na jego prośbę.

47 John N. McMahon z CIA, memorandum dla Sekretarza Stanu, Sekretarza Obrony i Asystenta Prezydenta do spraw Narodowego Bezpieczeństwa, 23 stycznia 1981 r., Raporty Kuklińskiego...; J. E is l e r, Polskie miesiace, czyli kryzys(y) w PRL, Warszawa 2008, s. 207-208; Historia dyplomacji polskiej, t. VI, 1944/45-1989, red. Wojciech Materski, Waldemar Michowicz, Warszawa 2010, s. 802-804; W. J a r u z e 1 s k i, Stan wojenny..., s. 44 pisze, że delegacja wracała z Moskwy z uczuciem ulgi w przekonaniu, że zagrożenie interwencją zostało odroczone na jakiś czas. 
za miesiąc, dwa lub pięć. Wstrzymanie przygotowań nie jest dla nich problemem. Zdaniem Brementa impulsem do podjęcia decyzji o interwencji było zwolnienie 27 listopada z aresztu Narożniaka i Sapieły, co dla Rosjan było ustępstwem nie do zaakceptowania. Sowieckie Biuro Polityczne na mającym wówczas miejsce posiedzeniu uznało, że interwencja w Polsce nastąpi, jeśli władze polskie nie dostarczą wiarygodnych zapewnień, że podobne sytuacje się nie powtórzą. Nazajutrz, 28 listopada siły Związku Sowieckiego, Czechosłowacji i Niemiec Wschodnich przystąpiły do przygotowań, tak aby 8 grudnia osiągnąć gotowość do inwazji. Szczyt moskiewski (4-5 grudnia) był ostatnią szansą dla Kani. Miał wówczas zapewnić, że na przyszłość jego rząd nie dopuści do nielegalnych strajków i działalności kontrrewolucyjnej. Wedle rumuńskich źródeł spośród obecnych w Moskwie przywódców tylko Erich Honecker z NRD domagał się natychmiastowej interwencji. Zdaniem Brementa Polacy opuszczali Moskwę raczej w przekonaniu, że ZSRR gotów jest dać im więcej czasu na rozwiązanie problemów. Sowieccy przywódcy najprawdopodobniej przyjęli stanowisko „wait and see”. Szczyt moskiewski zakończył prace na trzy dni przed datą gotowości do planowanego ataku. Groźbą Rosjanie osiągnęli jeden, bardzo ważny cel polityczny: przekonali wszystkie warstwy polskiego społeczeństwa, że granice sowieckiej tolerancji zostały już osiągnięte. W przekonaniu Brementa Rosjanie nie zaatakują w weekend. Raczej utrzymywać będą stan gotowości przez szereg kolejnych tygodni albo i dłużej, dopóki nie stwierdzą, że wszyscy w Polsce, w tym partia, Kościół i robotnicy, pojęli, iż rząd działa „pod groźba pistoletu” (under the gun) i Rosjanie nie cofną się przed atakiem, jeśli to, co w Moskwie określa się jako anarchię i „,działalność kontrrewolucyjną”, będzie się rozwijać poza wszelką kontrolą ${ }^{48}$.

Do spodziewanej w nocy z 7 na 8 grudnia inwazji w istocie nie doszło. Prezydent Carter był jednak przekonany, że Moskwa w końcu na nią się zdecyduje, gdyż ruch Solidarności jest po prostu sprzeczny z założeniami systemu totalitarnego. Brytyjski ambasador w Waszyngtonie Nicko Henderson oceniał w rozmowie z Brzezińskim, że inwazja równałaby się końcowi Polski i ubolewał nad ugodowością Niemców i Francuzów, dowodzącą słabości Zachodu. Brzeziński nie ustawał w wysiłkach, by nadać sowieckim przygotowaniom do inwazji jak największy rozgłos. Jego zdaniem wytrącało to z rąk Rosjan element zaskoczenia, a Polakom uświadamiało, że do inwazji może dojść, co powinno sprzyjać uspokojeniu nastrojów. 9 grudnia Brzeziński zapisał w dzienniku, że wedle danych wywiadu 27 sowieckich dywizji jest gotowych do interwencji. Przygotowane są oddziały transportowe, urządzenia szpitalne, a na samoloty transportowe ładuje się wyposażenie spadochroniarzy. Tym razem CIA oceniło, że inwazja nastąpić może pomiędzy 11 a 16 grudnia. Stanfield Turner potwierdzał, że w praktyce nie ma żadnej obrony przed inwazją ze Wschodu. Brzeziński w ramach ,zniechęcania” Rosjan nie krył w rozmowach z politykami i dziennikarzami, że działania Rosjan mogą, mimo ich woli, doprowadzić do zwróconego przeciwko nim sojuszu Europy Zachodniej, Stanów Zjednoczonych, Japonii, a nawet Chin ${ }^{49}$.

19 grudnia Zbigniew Brzeziński donosił prezydentowi, że inwazja odłożona została na „nieokreślona przyszłość”. Zasadniczą przyczyną tej decyzji była, jego zdaniem,

48 FRUS, 1977-1980, vol. VI, Soviet Union, dok. 313, Marshall Brement do Zbigniewa Brzezińskiego, 9 grudnia 1980 r., na dokumencie akceptująca adnotacja Brzezińskiego, s. 918. O sytuacji gospodarczej Związku Sowieckiego pisze: Jegor Gajdar, Upadek imperium. Nauka dla wspótczesnej Rosji, Warszawa 2016, s. 161-397.

${ }^{49}$ Z. Brzezińs ki, Cztery lata w Biatym Domu..., aneks, notatki z 9 i 10 grudnia, s. 557-559. 
skuteczność zachodniej propagandy, która przekonała Kreml, że Zachód zastosuje „zmasowane" sankcje polityczne i ekonomiczne. Siły inwazyjne pozostają jednak w stanie podniesionej gotowości i w każdej chwili mogą do Polski wkroczyć. Inwazja nastąpiłaby pod pretekstem manewrów wojsk Układu Warszawskiego ${ }^{50}$.

Prezydent Jimmy Carter w swoich pamiętnikach odnotował:

z początkiem grudnia, w niespełna rok po tym, jak wojska sowieckie najechały Afganistan, byliśmy przekonani, że ich siły przygotowują się do ataku na Polskę... Obserwowaliśmy starannie sowieckie przygotowania wojskowe. 15 do 20 dywizji było gotowych do działania; po raz pierwszy czeskie i sowieckie siły prowadziły wspólnie nocne ćwiczenia. Rosjanie nadzorowali szlaki inwazyjne, zorganizowali system komunikacyjny na terenie całej Polski, prowadzili intensywne loty rekonesansowe od strony Czechosłowacji, Niemiec Wschodnich i utrzymywali swoje siły zbrojne w stanie wysokiej gotowości ${ }^{51}$.

Brzeziński zaś napisał:

w krytycznych dniach grudniowych nie trzeba było przekonywać Cartera o historycznym znaczeniu powstrzymania działań radzieckich. Gotów był wykorzystać cały prestiż amerykański i zająć odpowiednią postawę, aby przekonać Rosję, że tym razem reakcja Stanów Zjednoczonych i całego świata może się okazać surowsza niż po inwazji na Afganistan. Stali za nim ponadto jego wszyscy główni doradcy i brak sprzeciwu w tej sprawie był rzeczą godną uwagi ${ }^{52}$.

Nie pomniejszając znaczenia ,,zachodniej propagandy” i działań mających na celu „zniechęcanie” Rosjan, zasadniczą przyczyną rezygnacji Moskwy z natychmiastowej interwencji w Polsce były względy wojskowe, w tym niechęć do uwikłania się w kolejny, obok Afganistanu, konflikt zbrojny i obawa przed skutkami zapowiadanej przez Brzezińskiego współpracy wojskowej pomiędzy Stanami Zjednoczonymi i Chinami. Tym razem, w odróżnieniu od kryzysów 1956 i 1968 r., postanowiono w Moskwie zastosować bardziej wyrafinowane środki dla ochrony swych interesów w Polsce, pozostawiając zadanie rozprawienia się z potężnym ruchem Solidarności, jak to Anglicy określali, ,, miejscowym quislingom "53.

\section{Bibliografia}

Archiwalia

National Archives, Londyn

NA, FC028/4164, FCO28/4165

Archiwum NATO, Bruksela, C-VR (80), PO(80)133

${ }^{50}$ FRUS 1977-1980, vol. VI, Soviet Union, dok. 314, asystent do spraw narodowego bezpieczeństwa. Z. Brzeziński do prezydenta, 19 grudnia 1980 r., s. 921; Z. B r z e z iń s k i, Cztery lata w Białym Domu..., s. 446.

${ }^{51}$ Cyt. za: FRUS 1977-1980, vol. VI Soviet Union, dok. 309, Editorial Note, s. 911.

52 Z. Brzeziński, Cztery lata $w$ Biatym Domu..., s. 446; Z. Brzeziński odnotował też, że wysiłki Stanów Zjednoczonych wzmocniła ostro sformułowana depesza Giscarda d’Estaing do przywódców sowieckich, choć równocześnie stanowisko Niemiec zaczęło być chwiejne, s. 445; Andrzej Wielowiejski przypisuje zasługę zniechęcenia Rosjan do interwencji w Polsce w grudniu 1980 r. działaniom Ryszarda Kuklińskiego i ostrym naciskom prezydenta Cartera na Breżniewa, zob. A. Wielowiejski, Losowi na przekór, Warszawa 2015, s. 327.

53 Wojciech Jaruzelski we wspomnieniach przypisuje decyzję Moskwy o odroczeniu inwazji jednolitemu stanowisku polskiej ekipy i niewyczerpanym jeszcze przez nią możliwościom w dążeniu do odzyskania kontroli nad sytuacją, zob. W. J a r u z e ls k i, Stan wojenny..., s. 45. 
Dokumenty publikowane

Foreign Relations of the United States (FRUS) 1977-1980, vol. VI, Soviet Union, https://history. state.gov/historicaldocuments/frus1977-80v06/d310

Raporty przekazane przez płk. Kuklińskiego http://wyborcza.pl/1.768426056610,

Wspomnienia

Brzeziński Zbigniew, Cztery lata w Biatym Domu. Wspomnienia Doradcy do spraw Bezpieczeństwa Państwa 1977-1981. Przedruk za: Polonia Book Fund Ltd., London 1986

Jaruzelski Wojciech, Stan wojenny. Dlaczego... Współpraca Marek Jaworski, Włodzimierz Łoziński, Warszawa 1992

Kania Stanisław, Zatrzymać konfrontację, Wydawnictwo „BGW”, 1991

Rakowski Mieczysław F., Dzienniki polityczne 1979-1981, Warszawa 2004

Wielowiejski Andrzej, Losowi na przekór, Warszawa 2015

Opracowania

Eisler Jerzy, Polskie miesiace, czyli kryzys(y) w PRL, Warszawa 2008

Friszke Andrzej, Rewolucja Solidarności 1980-1981, Kraków 2014

Gajdar Jegor, Upadek imperium. Nauka dla wspótczesnej Rosji, Warszawa 2016

Holzer Jerzy, ,, Solidarność” 1980-1981. Geneza i historia, Warszawa 1984

Jażborowskaja Iniessa S., Moskwa a ,kryzys polski” lat 1980-1981, [w:] Białe plamy. Czarne plamy. Sprawy trudne w relacjach polsko-rosyjskich (1918-2008), red. Adam Rotfeld, Anatolij Torkunow, Warszawa 2010

Paczkowski Andrzej, Moskwa a ,kryzys polski” lat 1980-1981, [w:] Białe plamy. Czarne plamy. Sprawy trudne $w$ relacjach polsko-rosyjskich (1918-2008), red. Adam Rotfeld, Anatolij Torkunow, Warszawa 2010

Rojek Wojciech, Historia nowoczesnych stosunków międzynarodowych, Warszawa 2010

Weiser Benjamin, Ryszard Kukliński. Życie ściśle tajne, Warszawa 2005

Historia dyplomacji polskiej, t. VI 1944/45-1989, red. Wojciech Materski, Waldemar Michowicz, Warszawa 2010

Andrzej Kastory

Western Powers in the Face of the Crisis in Poland in December 1980

Summary

The events that took place in Poland in summer and autumn of 1980 drew strong interest from the Western countries. In the United States, the potential literal execution of the Gdańsk Agreement was considered an existential threat for the communist system in Poland. The British embassy in Warsaw indicated that Russians had a reason to see "anti-socialist elements" in Poland. There are approximately, the British wrote, 32 millions of them, and if Poland were an island on the Pacific Ocean, it would not have a communist regime. It is not an island though. The Foreign Office estimated that the consequences of Soviet intervention in Poland would have been lower than in the case of Afghanistan, as the latter regarded a new area, posing a potential threat to the vital interests of the West. Another subjugation of Poland would not disturb the strategic or political balance in Europe. Russia would consider the consequences of intervention in Poland temporary and the risks of the lack of intervention permanent, as inactivity would be an incentive for other Warsaw Pact states. 
Russia planned to launch the manoeuvres of Soviet the military supported by Czechoslovakian and East German divisions on 8 December. Ryszard Kukliński immediately informed the USA about this fact. It was obvious that the manoeuvres could easily turn into an armed intervention. In his letter of 3 December 1980 to Leonid Brezhnev, President Jimmy Carter emphasised that the United States was utterly committed not to take advantage of the situation in Poland and not to threaten the justified interests of the Soviet Union in the region and that they cared only about letting the Polish nation deal with its internal problems, as imposing certain decisions would have had a negative impact on American-Soviet relations. On 5 December, the Prime Minister of Canada, Pierre Trudeau, wrote a similar letter to Brezhnev. He pointed out that Canada understood the interests of the Soviet Union, in particular regarding Central Europe and stated that the allegations that Western state wanted to use the events in Poland against the Soviet Union were unfounded.

The anticipated invasion on the night of 7 and 8 December did not occur indeed. President Carter was convinced though that Moscow would finally invade, as the Solidarność movement was wholly counter to the rationale of a totalitarian system. On 19 December, Zbigniew Brzeziński informed the president that the invasion had been postponed indefinitely. He believed that the basic cause was the effectiveness of Western propaganda, which convinced the Kremlin that Western countries would apply mass political and economic sanctions.

Whilst not undervaluing the importance of Western propaganda and actions aiming at discouraging Russia, the root cause of withdrawing from immediate intervention in Poland were military considerations, including reluctance to engage in another armed conflict in addition to Afghanistan and concern about military cooperation between the United States and China announced by Brzeziński. Therefore, this time, unlike during the crises of 1956 and 1968, Russia decided to use more refined measures to protect its interests in Poland, leaving the task of dealing with the enormous Solidarność movement to local quislings, as the English called them.

Key words: United States Department of State, Foreign Office, NATO Council, Polish crisis of 1980; threat of intervention. 